10. Avdeeva L.YU., Makarenko A.A (2017) Vplyv efektiv hidrodynamichnoyi kavitatsiyi na elektrokhimichni vlastyvosti vody. Scientific Works, Odesa. 81, 1. P.105-110

Отримано в редакцію 11.05.2018

Прийнято до друку 24.06.2018
Received 11.05.2018

Approved 24.06.2018

\title{
ВПЛИВ ШВИДКОСТІ РУХУ ПОВІТРЯ НА ПРОЦЕС КОНВЕКТИВНО-ТЕРМОРАДІАЦІЙНОГО СУШІННЯ ЯБЛУЧНИХ СНЕКІВ
}

\author{
Малежик І. Ф., Д-р техн. наук, професор, Дубковецький І. В., канд. техн. наук., доцент, \\ Стрельченко Л. В., аспірант \\ Національний університет харчових технологій, м. Київ
}

\begin{abstract}
Анотація. В процесі розвитку технічного прогресу харчова промисловість вимагає нових технологічних рішень для підвищення якості харчових продуктів. Сегмент ринку снеків в наш час дуже поширений та популярний серед споживачів, проте якість цих снеків бажала б бути вищою, а асортимент різноманітнішим. Саме ия проблема наштовхнула нас на створення нового продукту з відмінними харчовими властивостями та збалансованим хімічним складом. Маючи базу попередніх досліджень оптимальних параметрів сушіння снеків, необхідно визначити вплив швидкісті руху повітря на прочес сушіння. Швидкість ичиркулящії повітря в сушильному пристрої - найважливіший параметр процесу сушіння. Чим вище швидкість цииркуляції, тим, за інших рівних умов, менша тривалість процесу, вища продуктивність сушіння, менша нерівномірність сушіння матеріалу, більші витрати електроенергії і в більшості випадків вища собівартість.

Нами запропоновано комбінувати два способи підведення теплоти при сушінні - терморадіаційний $i$ конвективний, щзо дозволило зменшити відносну вологість повітря $i$ збільшити рушійну силу процесу $в$ порівнянні з сушінням інфрачервоними променями. Для цьього була спроектована і виготовлена сушильна установка, яка дозволяє сушити терморадіаційним і конвективним способами як окремо, так $i$ їх поєднанням. В роботі викладені результати досліджень впливу швидкості ичиркуляції сушильного агента на основні параметрів процесу сушіння в радіаційно-конвективній установці періодичної дії. Механізм та інтенсивність перенесення вологи у матеріалі залежать від взаємопов'язаного комплексу процесів порушення зв'язку вологи з матеріалом та дифузї парогазового середовища через капілярно-порову структуру матеріалу. В даній роботі встановлені залежності основних тепломасообмінних характеристик конвективно-терморадіаційного сушіння яблучних снеків від швидкості руху повітря.
\end{abstract}

Ключові слова: снеки, бланшування, сировина, сушіння, швидкість повітря, температура, вологовміст.

\section{INFLUENCE OF AIR TRAFFIC SPEED ON THE PROCESS OF CONVECTIVE-THERMORADIATIVE DRYING OF APPEAL ANIMALS}

\author{
Malezhick I.F., Dr. Of Tech. Sci., prof., Dubkovetskiy I.V., PhD, Associate prof., \\ Strelchenko K.V., postgraduate student \\ National University of Food Technologies, Kyiv, Ukraine
}

\begin{abstract}
In the process of developing technical progress, the food industry requires new technological solutions to improve the quality of food products. The snack market segment is nowadays very popular and popular among consumers, but the quality of these snacks would be desirable, and the assortment is more diverse. This problem has led us to create a new product with excellent nutritional properties and a balanced chemical composition. Having a base of preliminary studies of the optimum parameters of drying snakes, it is necessary to determine the effect of the speed of air movement on the drying process. The rate of air circulation in the dryer is the most important parameter of the drying process. The higher the circulation velocity, the more equal conditions, the shorter the duration of the process, the higher the drying performance, the less uneven material drying, the greater the cost of electricity and in most cases the higher cost.

We are proposed to combine two methods of supplying heat during drying - thermal radiation and convection, which allowed to reduce the relative humidity of air and increase the motive force of the process compared with the drying of infrared rays. For this purpose, a drying plant was designed and manufactured, which allows drying by thermal radiating and convection methods both individually and in combination. The paper presents the results of studies on the influence of the circulation velocity of a drying agent on the main
\end{abstract}


parameters of the drying process in a radiation-convective installation of periodic action. The mechanism and intensity of the transfer of moisture in the material depend on the interrelated complex of processes of violation of the connection of moisture with the material and the diffusion of the vapor-gas medium through the capillarypore structure of the material. In this paper, the dependences of the main heat and mass-exchange characteristics of convective thermo-radiation drying of apple snakes on the velocity of air are determined.

Keywords: snacks, blanching, raw material, drying, air speed, temperature, moisture content.

Вступ. Снеки користуються значним попитом серед споживачів, хоча багато хто й не ототожнює цей продукт зі снеком. Основна маса споживачів називає це швидким перекусом, в ряд якого входять: батончики, сухарики, печево з сирним соусом і тому подібне. Серед фруктових снеків це яблучні чіпси, сушені яблука, фруктові асорті у вигляді цукатів. 3 перечислених продуктів найбільшим попитом користуються яблучні чіпси. Але мало хто замислюється про харчову цінність продукту та його безпечність при постійному вживанні, адже сама технологія виготовлення чіпсів передбачає таку технологічну операцію як «обжарювання», яке здійснюється в олії. Продукт оброблений таким способом при тривалому споживанні може призвести до надмірної ваги людини та погіршення стану здоров'я через канцерогенні речовини.

Аналізуючи ринок «швидких перекусів» за останні роки вченими проводилися дослідження по обробці яблучного напівфабрикату лимонною кислотою [1], солями кальцію, пастеризованим молоком [2], мальтозним сиропом [3] та заморожуванням [4]. Однак така обробка впливала не лише на якість процесу сушіння, а й призводить до зміни структури та фізико-хімічних характеристик самого продукту (наприклад, післясмак молока; рихла, деформована структура снека через заморожування).

Матеріали та методи досліджень. Нами розроблена і запатентована технологія виготовлення яблучних снеків із збалансованим хімічним складом без додавання барвників, підсилювачів смаків та консервантів [5], що дозволить використовувати цей продукт для широкого загалу. Сировиною для сушіння $\epsilon$ яблука сорту «Голден Делішес» та «Чемпіон», завдяки високому початковому вмісту в них сухих речовин та меншій активності ферменту пероксидази.

Попередньо підготовлені яблука бланшували протягом 90 секунд в 30 \%-му цукровому сиропі 3 додаванням органічної (лимонної) кислоти та антиоксиданту. Сушіння виконували в імпульсному режимі нагрів-охолодження 3 довжиною хвилі в діапазоні 1,2-4 мкм з температурою сушіння яблучних снеків 60 ${ }^{\circ} \mathrm{C}$ при насипній масі продукту в 200 г. Конвективне підведення теплоти здійснювалося від зовнішнього ТЕНу 2,5 кВт/м²; відстань між терморадіаційними ТЕНами і продуктом складала 14 см [6]. 3 метою інтенсифікації процесу сушіння було введено в сушарку рециркуляцію повітря 50/50 \%.

Для встановлення оптимальної швидкості руху теплоносія на основі літературних джерел нами було обрано певний діапазон швидкостей: $2,8 \mathrm{~m} / \mathrm{c}, 3,5 \mathrm{~m} / \mathrm{c}, 4,5 \mathrm{~m} / \mathrm{c}$ та $5,5 \mathrm{~m} / \mathrm{c}$. Використання швидкості менше $2,8 \mathrm{~m} / \mathrm{c}$ призводить до нераціонального використання ресурсів сушарки, бо робота не на повну потужність призводить до погіршення сировини для сушіння з руйнуванням вітаміну С та окисленням напівфабрикату природнім ферментом пероксидази. А використання швидкості понад 5,5 м/с не дає бажаного ефекту, бо волога напівфабрикату з внутрішніх шарів до периферії не встигає надходити.

Результати досліджень. Обговорення результатів. На основі отриманих даних були побудовані криві сушіння (рис. 1), що характеризують зміну інтегрального вологовмісту $W^{c}$ залежно від часу $\tau$. Звідси видно, що період прогріву для всіх зразків відсутній, а видалення вологи відбувається прямопропорційно збільшенню руху повітря.

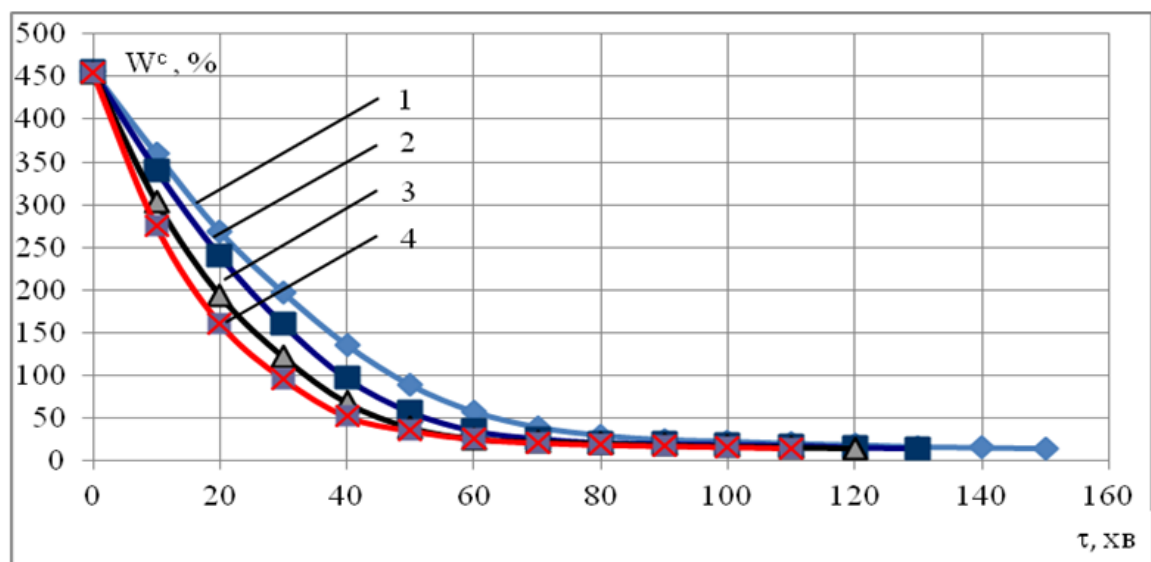

Рис.1. Криві сушіння бланшованої сировини при різних швидкостях повітря: $1-2,8$ м/с; 2- 3,5 м/с; 3- 4,5 м/с; 4- 5,5 м/с.

Апроксимуючи дані першого та другого періодів сушіння, вивели рівняння залежності вологовмісту $W^{c}$ від часу сушіння $\tau$ і швидкості руху повітря $v: W^{c}=(-1,99 v-3,89) \tau+468,2 \mathrm{e}^{-0,009 v}$ при $R^{2}=0,98$, а в другому періоді $-W^{c}=(-12149 \cdot v+72556) \cdot \tau^{0,042 \cdot v^{2}-0,25 \cdot v-1,24}$ при $R^{2}=0,96$,

Наукові праці, Том 82, випуск 1

Scientific Works, Volume 82, Issue 1 
де $W^{c}$ - вологовміст, \%; $\tau$ - час, хв; $v$ - швидкість руху теплоносія, м/с; $R^{2}$ - коефіцієнт кореляції.

В результаті обробки кривих сушіння отримані залежності швидкості сушіння частинок яблук від вологовмісту (puc. 2), що дають змогу проаналізувати динаміку зміни сушіння зразків. При виведенні рівняння кінетики сушіння з експериментальних залежностей $d W^{c} / d \tau$ від $W^{c}$ встановили, що на першій стадії швидкість сушіння можна приблизно вважати постійною. А починаючи 3 2-го періоду сушіння спостерігається зростаюча залежність з різною характерністю від швидкості руху повітря.

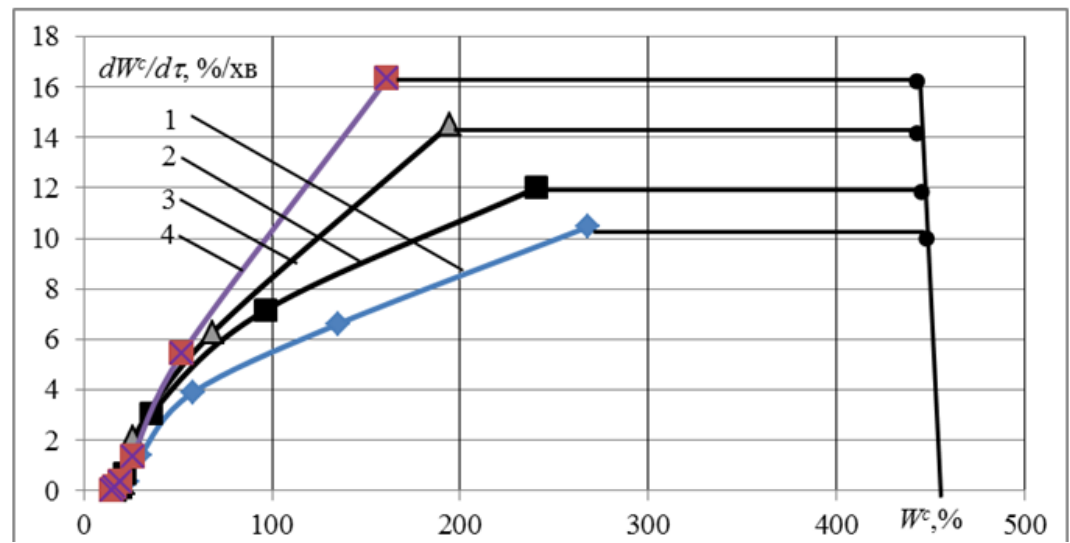

Рис.2. Криві швидкості сушіння бланшованої сировини при різних швидкостях повітря: 1-2,8 м/с; 2- 3,5 м/с; 3- 4,5 м/с; 4- 5,5 м/с.

Проаналізувавши другий період сушіння, вивели для всіх зразків апроксимаційні рівняння залежності швидкості сушіння від вологовмісту $W^{c}$ продукту і швидкості руху теплоносія v:

$d W / d \tau=(1,24 v+0,13) \mathrm{W}^{\mathrm{c}}+3,6036 v+0,271$ при $R^{2}=0,99$.

На основі обробки графіків кривих сушіння і швидкості сушіння визначили залежності коефіцієнтів швидкості сушіння в першому і в другому періодах та одержали апроксимуючі рівняння (puc. 3).

При дослідженні періодів сушіння швидкість процесу сушіння визначали за станом навколишнього середовища і умовами сушіння, а повний потік вологи виражався через об'ємний коефіцієнт масовіддачі (5):

$$
\mathrm{J}=\mathrm{dW}^{\mathrm{c}} / \mathrm{d} \tau=\beta\left(\mathrm{x}_{\mathrm{r}}-\mathrm{x}\right)=\beta\left(\mathrm{x}_{1}-\mathrm{x}\right),
$$

де $\mathrm{x}_{\Gamma}$ - вологовміст повітря (кг/кг) на межі частинки, який вважається рівноважним; $\mathrm{x}_{\mathrm{r}}=\mathrm{x}_{1}-$ вологовміст повітря при постійній швидкості (перший період) сушіння (кг/кг), який знаходимо за психрометричними даними. Молярна маса води $\mathrm{M}_{\mathrm{B}}=18$, повітря $\mathrm{M}_{\mathrm{n}}=29$, відносна вологість повітря $\varphi=64 \%$. Парціальний тиск насиченої пари $\mathrm{P}$ при температурі $\mathrm{t}$ знаходимо з таблиць, а мольні долі $\mathrm{m}$ - зі співвідношення $\mathrm{m}_{1}=\mathrm{Pt}_{1} /\left(1-\mathrm{Pt}_{1}\right), \mathrm{Pt}_{1}=\mathrm{Pt} / 760$. При температурі $21{ }^{\circ} \mathrm{C} \mathrm{Pt}_{21}=18,66 / 760=0,025$.

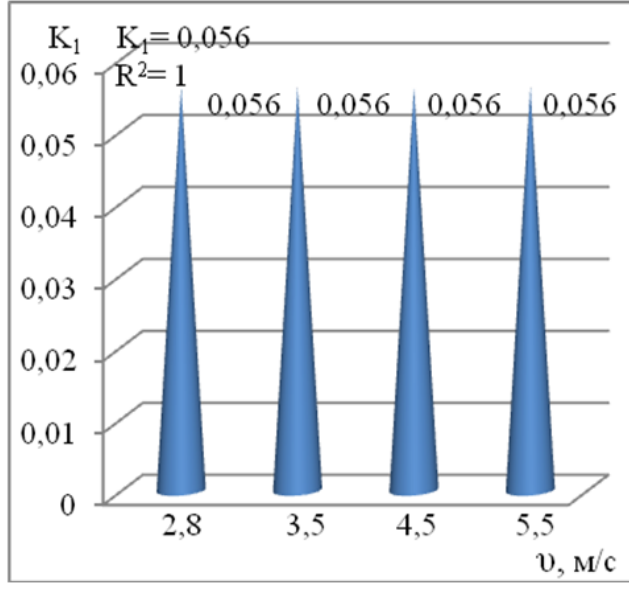

$a$

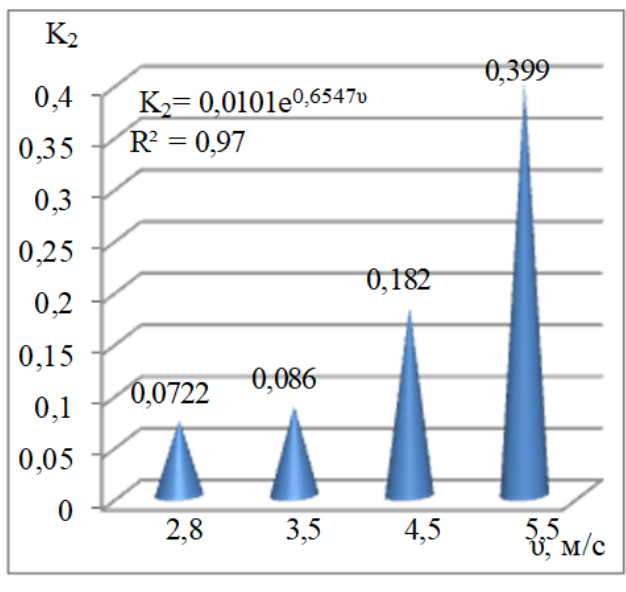

$\sigma$

Рис. 3. Коефіціснти швидкості сушіння для снеків в першому (3 а) та другому періодах сушіння (3 б) при різній швидкості руху повітря.

Молярна частка при $21{ }^{\circ} \mathrm{C} \mathrm{m}_{2}=\mathrm{Pt}_{21} \varphi /\left(1-\mathrm{Pt}_{21}\right)=0,016$. Вологовміст в першому періоді знаходиться за формулою (6)

Вологовміст $\mathrm{x}=\left(\mathrm{M}_{\mathrm{B}} / \mathrm{M}_{\mathrm{n}}\right)\left(\mathrm{m}_{2} /\left(1-\mathrm{m}_{2}\right)\right)=0,01$.

$$
\mathrm{x}_{1}=\left(\mathrm{M}_{\mathrm{B}} / \mathrm{M}_{\Pi}\right)\left(\mathrm{m}_{1} /\left(1-\mathrm{m}_{1}\right)\right) .
$$


Обробкою експерименту за допомогою програми MathCad отримано залежність коефіцієнта масовіддачі від швидкості руху повітря $\beta=\mathrm{f}(\mathrm{v})$ (рис. 4).:

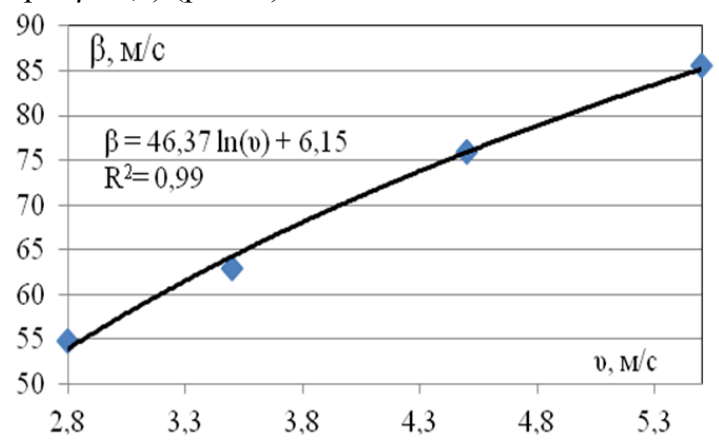

Рис. 4. Залежність коефіцієнта масовіддачі від швидкості руху повітря.

При обробці даних конвективно-терморадіаційного процесу сушіння визначено витрати енергії для всіх зразків снеків в кВт·год на кг вихідної сировини (puc. 5 a) і в МДж/кг випареної вологи (puc.5 б).
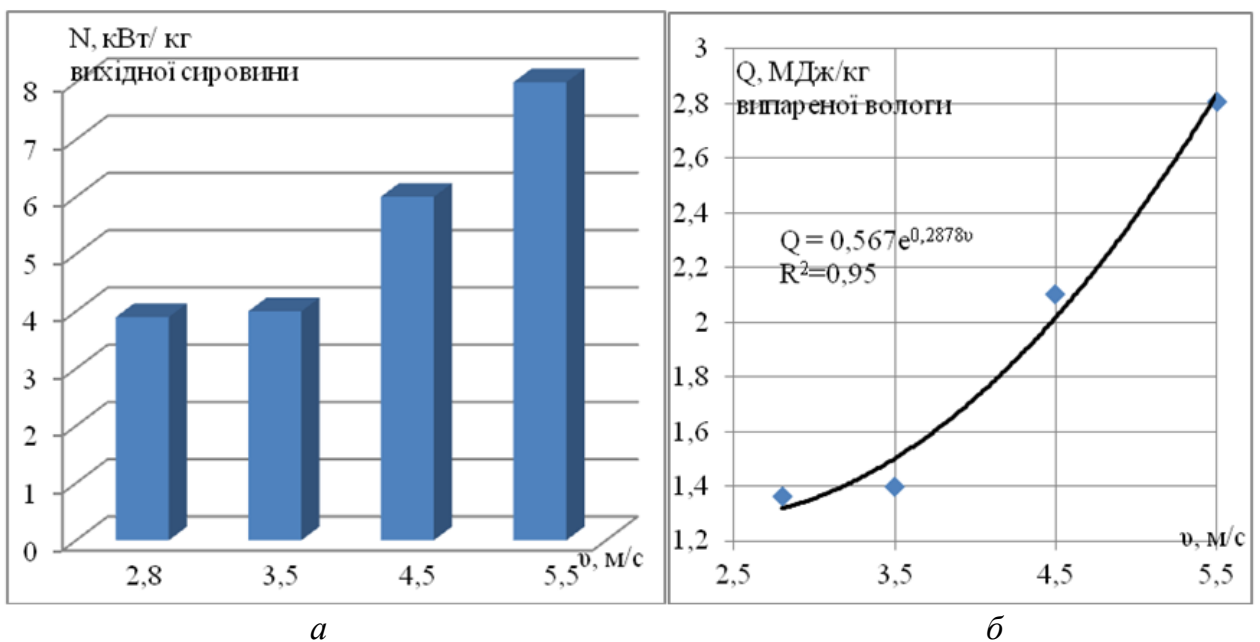

Рис. 5. Витрата електроенергії на 1 кг вихідної сировини (5 a) і на 1 кг випареної вологи (5 б) при різних швидкостях повітря.

3 рисунка видно, що найвищі витрати енергії були для снеків, що сушилися при швидкості повітря 5,5 м/с - 8 кВт*год/на кг вихідної сировини, а найнижчі - 3,9 кВт*год/на кг вихідної сировини для снеків, що висушувалися при швидкості повітря 2,8 м/с. Дане явище пояснюється тим, що зі збільшенням швидкості повітря скорочується час сушіння. Апроксимуючи дані витрат енергії в залежності від швидкості повітря під час сушіння вихідної сировини (бланшованих частинок яблук), вивели рівняння $\mathrm{Q}=$ $0,1494 \mathrm{~N}^{2}-0,6787 \mathrm{~N}+2,0468$ при $\mathrm{R}^{2}=0,99$, де $\mathrm{N}$ - швидкість теплоносія під час сушіння зразків снеків.

Дані результати чітко корелюються з властивостями і хімічним складом яблучних снеків (табл. 2).

\section{Хімічний склад яблук та снеків, отриманих при різних швидкостях повітря}

\begin{tabular}{|l|c|c|c|c|c|c|}
\hline \multirow{2}{*}{ Найменування показника } & \multicolumn{2}{|c|}{$\begin{array}{c}\text { Яблука } \\
\text { (істівна частина) }\end{array}$} & \multicolumn{3}{|c|}{ Снеки сушені при швидкостях, м/с } \\
\cline { 2 - 7 } & свіжі & сушені & 2,8 & 3,5 & 4,5 & 5,5 \\
\hline Сухі речовини яблук, \% & 14,0 & 84 & 14,0 & 14,0 & 14,0 & 14,0 \\
\hline Моно - та дицукри, \% & 10,5 & 61,0 & 60,5 & 62,8 & 64,8 & 66,9 \\
\hline Органічні кислоти , \% & 0,43 & 2,4 & 1,1 & 1,5 & 1,7 & 2,0 \\
\hline Пектинові речовини, \% & 1,0 & 4,6 & 4,4 & 4,0 & 3,3 & 2,9 \\
\hline Клітковина, \% & 1,1 & 4,4 & 4,0 & 3,6 & 3,2 & 3,0 \\
\hline Мінеральні речовини, \% & 0,7 & 3,1 & 3,1 & 3,5 & 3,2 & 3,4 \\
\hline Вітамін С, мг \% & 3,7 & 2,9 & 4,9 & 6,9 & 7,6 & 8,4 \\
\hline
\end{tabular}


Для чотирьох отриманих зразків снеків проведено органолептичний аналіз та зроблена їх дегустаційна оцінка. При цьому враховували такі показники як притаманність кольору, вираженість смаку, аромату, легкість розжовування та післясмак. Проте для остаточного визначення продукту проведено аналіз харчової цінності отриманих зразків за їх хімічним складом. В якості контрольного зразку було обрано сушені яблука конвективно-терморадіаційним методом (табл. 2).

3 таблиці видно, що снеки виготовлені з яблук «Голден Делішес» при швидкості повітря 5,5 м/с $є 3$ найкращим хімічним складом. Так, наприклад, через незначну швидкість повітря (2,8 м/с) можна пояснити високий вміст пектинових речовин (4,4 \%), адже під впливом температури і більш тривалого терміну сушіння відбувається перехід протопектину в пектин. Але тому, що сушіння здійснюється до вмісту вологи в продукті 8-10 \%, то ці зміни не впливають на органолептику готового продукту, але позначаються на харчовій цінності снеків.

Висновки. Результати досліджень процесу сушіння снеків конвективно-терморадіаційним способом при різних швидкостях повітря: 2,8 м/с, 3,5 м/с, 4,5 м/с та 5,5 м/с показали, що найкращою швидкістю $\epsilon$ 5,5 м/с. Дана швидкість сприяє максимальному збереженню вихідних показників сировини, що в подальшому дозволяє отримати готовий продукт з високими органолептичними та і фізико-хімічними показниками. До того ж витрата електроенергії під час сушіння знижується на 25-30 \%. Процес сушіння вдалося інтенсифікувати ще за рахунок імпульсного введення енергії «нагрів-охолодження» та рециркуляції повітря в сушарці.

\title{
Література
}

1. Doymaz, İbrahim. Effect of citric acid and blanching pre-treatments on drying and rehydration of Amasya red apples [Text] / Food and Bioproducts Processing - Amasya, 2010, 88(2-3), Pages 124-132.

2. María José Tavera-Quiroz. Development and Characterization of a Baked Snack from Rings of Green Apples [Text] / María José Tavera-Quiroz, Marina Urriza, Adriana Pinotti, Nora Bertola / Food and Bioprocess Technology - 2014, 7(8), Pages 2218-2227.

3. María José Tavera-Quiroz. Baked snack from green apples formulated with the addition of isomalt [Text]/ María José TaveraQuiroz, Marina Urriza, Adriana Pinotti,, Nora Bertola / Food Science and Technology - 2015, 62 (2), Pages 1004-1010.

4. Mishlenovich, Nevena. Comparison of the kinetics of osmotic dehydration of apple in sugar beet molasses and sucrose [Text]/ Journal on Processing and Energy in Agriculture - 2010, 14(1), Pages 32-35.

5. Спосіб виробництва яблучних снеків Патент на винахід України № 113587 МПК A23L 19/8, A23B 7/02 [Текст] / Малежик І.Ф., Дубковецький І.В., Бандуренко Г.М., Стрельченко Л.В. - а 201511035; заявл. 11.11.2015; опубл. 10.02.17, Бюл. № 3, с. 5.

6. I. Malejik Investigation of drying apple snack convection-termoradiatsiynym energy to wrap different power heaters [Text]/ I. Malejik, L. Strelchenko, I. Dubkovetsky / Proceeding of International Conference "Modern Technologies in the food Industry" - Chisinau, 2016, Pages 64-68.

\section{References}

1. Doymaz, İbrahim. (2010). Effect of citric acid and blanching pre-treatments on drying and rehydration of Amasya red apples. Food and Bioproducts Processing - Amasya, , 88(2-3), Pages 124-132.

2. María José Tavera-Quiroz, Marina Urriza, Adriana Pinotti, Nora Bertola. (2014). Development and Characterization of a Baked Snack from Rings of Green Apples. Food and Bioprocess Technology, 7(8), Pages 2218-2227.

3. María José Tavera-Quiroz, Marina Urriza, Adriana Pinotti,, Nora Bertola. (2015) Baked snack from green apples formulated with the addition of isomalt. Food Science and Technology, 62 (2), Pages 1004-1010.

4. Mishlenovich, Nevena. (2010). Comparison of the kinetics of osmotic dehydration of apple in sugar beet molasses and sucrose. Journal on Processing and Energy in Agriculture, 14(1), Pages 32-35.

5. Malezhik I.F., Dubkovetsky I.V., Bandurenko G.M., Strelchenko L.V. (2017) Method of production of apple snails. Patent for the invention of Ukraine № 113587 IPC A23L 19/8, A23B 7/02.

6. Malejik I., Strelchenko L., Dubkovetsky I. (2016) Investigation of drying apple snack convection-termoradiatsiynym energy to wrap different power heaters. Proceeding of International Conference "Modern Technologies in the food Industry" - Chisinau, , Pages 64-68.

Отримано в редакцію 07.05.2018

Received 07.05.2018

Прийнято до друку 24.06.2018

Approved 24.06.2018

УДК 661.015:542.61

DOI: http://dx.doi.org/10.15673/swonaft.v82i1.1002

\section{КІНЕТИКА ЕКСТРАГУВАННЯ КУПРУМУ СУЛЬФАТУ 3 ОДИНАРНОГО КАПІЛЯРА В УМОВАХ ВАКУУМУВАННЯ СИСТЕМИ}

\author{
Симак Д.М. канд. техн.наук, Склабінський В.І. д-р техн. наук, професор \\ Сумський державний університет, м.Суми
}

\begin{abstract}
Анотація. Досліджувався прочес екстрагування твердої речовини з капілярів циліндричної форми з метою визначення кінетики даного процесу. Твердою фазою служив купруму сульфат, який екстрагувався дистильованою водою. Екстрагування твердої фази складається з прочесу розчинення иільового компоненту та дифузії розчиненої речовини у капілярі. Лімітуючою стадією даного прочесу є дифузія компоненту всередині капіляру, що відбувається за законом молекулярної дифузії Фіка. У промислових умовах інтенсифікація прочесу екстрагування відбувається за рахунок подрібнення твердого матеріалу або збільшення температури. У роботі досліджувався процес екстрагування в умовах вакуумування си-
\end{abstract}

